Publisher homepage: www.universepg.com, ISSN: 2663-7782 (Online) \& 2663-7774 (Print)

https://doi.org/10.34104/bjah.019.14027

British Journal of Arts and Humanities

Journal homepage: www.universepg.com/iournal/bjah

\title{
Impact of Social Networking Sites on the Interpersonal Relationship among Teenager: A Sociological Analysis in the District of Bagerhat
}

\author{
Md. Shahin Parvez ${ }^{1}$, Md. Anisur Rahaman ${ }^{1}$, Kaniz Fatema $^{1}$, and Druti Rani Mondal ${ }^{1}$ \\ ${ }^{1}$ Dept. of Sociology, Bangabandhu Sheikh Mujibur Rahman Science, and Technology University, Gopalganj, Bangladesh. \\ *Correspondence: $\underline{\text { shahin.bsmrstu.soc18@gmail.com }}$
}

\begin{abstract}
Social Networking Sites (SNSs) are clearly becoming an authentic and chosen form of Communication. At present, utilize of SNSs amongst teenager students has enlarge, and utilize of SNS has extensive influence on these students in various ways, especially on their interpersonal relationships. The current study is placed in this context to determine the influence of SNS on interpersonal relationships of the teenager, and also find out the impetus of utilize, interest, as well as danger associated with SNS among the college student. In this study students finished a questionnaire that is utilize of SNSs from Khalilur Rahman Degree College, Shahed Hemayet Uddin Girl's High School, and Wajed Memorial Secondary School at Mollahat Upazila for creating primary data; It was establish that the utilize of SNS has result on interpersonal relationships of a teenager, particularly with their members of family, and friends. We were also found that how much average time they take up on SNSs, what kind of alter has been occurred in their face to face relationship. The study also tries to reveal the benefit, and danger associated with SNSs among teenagers. The study found that, although the SNSs have supported improve relationships among teenagers as friends, they have also create some negative effect such loss their time, increase crime, and immoral activities and increase their monthly expenditure among. It provides an outlook for exploring the technological implications on society in the domain of sociology.
\end{abstract}

Keywords: Social Networking Sites, Teenagers, Sociological Analysis, Impact, and Interpersonal Relationships.

\section{INTRODUCTION:}

Online Social networks have gained tremendous popularity among people all around the world, especially teenagers. Utilize of SNSs has become a popular and integral part of everyday communication in teenager life of Bangladesh. Newer developments in the technological world have made the internet and creative way for individuals, and families to communicate. People utilize SNSs such as Facebook, LinkedIn, Twitter, and Youtube to build, and sustain relationships with others. These SNSs let those who utilize them build personal profiles while linking with other users of the sites. SNSs also support teenager people to develop their friendship. Users can attach photographs, news, post what they are doing at any given period, and send personal or public messages to whomever they prefer. In this "information age," SNSs seem to be growing in favor rapidly, especially among teenager. In particular, college students create a large proportion of customers on social media networks. Many of these juvenile adults utilize social media networks to share with family, friends, and even 
strangers. According to Zeng (2013), a good project to enhance marketing is by utilizing social media to sell tourism products. Moreover, search engines have become one more necessary device because there is huge information on the online (Xiang and Gretzel, 2010).

Social networks play a major role in building, maintaining or even reviving relationships and improving teenagers learning skills. In this research we focused mainly on the impact of SNSs on teenager especially in college and school student and how SNSs change their relationship pattern. In most third world countries utilize of the internet has been made even more accessible by mobile phones. Today people are using the internet mostly to mix on social media, they chat, message, allowance photos, and stay in touch with friends and relatives worldwide. SNSs such as Friendster, World, Facebook, LinkedIn, and Myspace allow individuals to show themselves, articulate their social networks, and prove or maintain links with others. SNSs allow users to share knowledge, photos, news posts, activities, events, news, and interests with people in their system. Facebook users can also combine virtual groups based on similar interests, see what classes they have in ordinary, and learn each other's' hobbies, interests, musical tastes, and lovely relationship place through the profiles (Ellison et al., 2007). Teens mostly utilize the online for entertainment and for sharing with friends, and family. They have been favored since the year 2002, and have tempted, and fascinated tens of millions of Internet users (Boyd and Ellison, 2007).

The nature of relationships will be examined for the effect of SNSs on the quality and the pattern of the relationship. Youths utilize technology to keep in touch with friends, mediate romantic relationships, organize into social groups, support each other, and develop their own identities (Ito et al. 2010). The Usages of SNSs brought a lot of change among on interpersonal relationships teenagers and their family and friends. Social media cites to the mode of interactions amid people in which they build the share, exchange, and comment contents among themselves in virtual bodies, and networks (Shahjahan A.T.M and Kutub Uddin Chisty, 2014). Social networking tools like Twitter, Facebook, Flickr, LinkedIn, and Blogs have helped the creation, and share of ideas so quickly, and widely than the traditional media. Bangladesh Telecommunications Regulatory Commission (BTRC) statistics indicate that the country presently has around $70,000,000$ mobile phone users. Bangladesh is also feeling the hot of online SNSs (Thawhidul, 2008).

Online SNSs has become universally growing phenomena over the last decade (Nasrin Akter, 2014). It is a well known fact that young adults and teenagers are the most eager users of SNSs which have a large impact on their lives. The most attractive activities done by students, and users on SNSs revolve around looking at profiles of one another, searching for someone here, and there, updating one's personal profile, and eavesdropping. According to Vitak (2008), there are various reasons as to why individuals utilize SNSs. The main reason is for them to meet strangers, and become friends. The majority of participants of her research work (57\%) said that they were primarily introduced to those "friends" through nearest friends, which enlarged the prospect of such relationships developing into strong ties.

Folorunso (2010) managed a survey among participants of the University of Agriculture, Abeokuta in Nigeria, and examined the attributes of Diffusion of Innovations (DOI) theory towards utilize pattern of SNSs. Bicen and Cavus (2010) assessed the utilize of SNSs among participants in the Dept. of computer learning instructional technology, and found which SNSs are the most choice by students. Won Kim, and Sang-Won Lee (2009) properly indicate that today the college students utilize various SNSs, to stay linked with their friends, discover new "friends" and to share users - created contents, such as photos, videos, blogs and etc. Tiffany et al. (2008) millions of modern young adults utilize social networking study, 92 undergraduates accomplished a diary like assess each day for a week, reporting every day time utilize, and responding to an activities checklist to evaluate their utilize of the popular SNS, Facebook. Geetanjali Naidu \& Sunil Agrawal (2013) in today's scenario social media became a very helpful component in buying behavior decision making. It is influencing customer/consumer in a energetic manner. According to Berlinger (2000) virtual life experiences can destroy us the role of human contact we require for our 
physical, psychological, and social wellbeing. Kruat et al. (2002) found that repeated utilize of SNSs would result in a social circle declination. Mecheel (2010) recognize the role of the social networking on social relations. Shim Young-Soo (2007) recognizes the effect of the internet on the close communication of teenagers. Al-Otaibi (2008) aimed to recognize the major role of Facebook on the university's students of Saudi Arabia. The prevalence of utilize of Facebook among the universities students of Saudi Arabia constitute to $77 \%$. The major objectives of this study are to know the purpose of usages of SNS by the college students, to dig out the changes of interpersonal relationship pattern through social network site among teenagers, to determine benefits of using SNSs, and to identify the danger associated with SNSs.

\subsection{Rational of the Study}

The study looks at the impact of SNSs on interpersonal relationships among teenagers, its findings will be relevant because they will inform parents, teachers, students and all the relevant stakeholders on the effect of SNSs on the interpersonal relations among teenagers. The result of this study will create the students who in this study are being referred to as teenagers, to be aware of how SNSs influence their interpersonal relations. It will also help their teachers by suggesting some ways in order for them to relate to student's social activities especially with regards of using SNSs. The parents will be helped to understand their children's purpose to using SNSs and for them to be aware of the influence of SNSs that might affect their children. Finally, this study will help further studies of future researchers regarding the influence of SNSs on the interpersonal relationship of students.

\subsection{Conceptual Framework}

(a) Teenager - Teenager is a young person whose age falls within the range from thirteen through nineteen (13-19).

(b) SNSs - The full meaning of SNSs is Social Networking Sites.

(c) Social Networking Sites - SNS is a website that is designed to help people communicate and transfer information, news, photographs, etc. with a group. (d) Social Media - Social Media mention to the means of interaction among people in which they build, share, information and plan in virtual communities, and networks.

(e) Interpersonal Relationship - A bond between two or more user refers to an interpersonal relationship. An interpersonal relationship is a secure, deep or close association between two or more persons that may range in period from brief to enduring.

1.3 Limitations of the Study - This study is only limited to and within the reach of all those in the sample population who have access to the internet. It will also only cover students in boarding secondary schools because most of these students are from urban areas and they are familiar with SNSs. These limitations are due to the limited time schedule.

\section{Theoretical Frameworks}

There are several theories that should be introduced in this paper for they are securely related to the content which can aid explain the users' behaviors. The theories are Technology Determinism, Social Penetration, and Uses, and Gratification.

\subsection{Technology Determinism - Technological} Determinism is the beliefs by Thorstein Veblen (2010) that technology examines social, and cultural changes (history), and that it is the key governing force in community. Technological Determinism Theory discusses how technology advances impacts every areas of society including approaches of communication. The five key beliefs of Technological Determinism pointed out by WaratKaruchit, 2013. As declared by Marshall McLuhan, the Canadian literary scholar during 1960s, it is the version that shapes, and controls the scale, and structure of human association and action (WaratKaruchit, 2013). He proclaimed that media is an addition of man, extending a man's vision, hearing, and touch through time and space.

2.2 Social Penetration - Social Penetration theory was made to discuss the improvement of interpersonal relationships that refers to the interchange process of behaviors between multiple users who are in the process of developing a relationship. Facebook, for example, users are able to set their solitude level (McCarthy, 2009). People are more likely to share 
more private information on SNSs than they would in close communication because the level of control is larger (Ledbetter et al., 2011).

2.3 Uses and Gratifications - In order to recognize the motivation and the purpose of Social Networking usage, Uses, and Gratifications Theory (UGT) was being examined. The Four basic requirements of UGT: Information, Entertainment, Personal identity, and Personal Relationship, and Social interaction. Since there are Facebook pages to subscribe, and it is nearly online twenty-four hours a day, users sustain information from their choice sources i.e. news, fun facts, up-coming events, etc (WaratKaruchit, 2013).

2.4 Network Society - The Spanish sociologist Manuel Castells built one of the most aspiring macro theories of our time, which attempts to explain, and elucidate power, economy, and social life in a world exchanged by globalization, and informatization. Through Castells, theory Researcher can understand that Information, and communication Technologies changing the structure of our society and also change our communication pattern, relationship pattern.

\section{METHODOLOGY:}

The Chapter covers the unit of the study such as the main method applied in the study, data collection process, sampling and data validation are discussed in this chapter. It constitutes the theoretical analysis of the body of methods and principals associated with a offshoot of knowledge.

3.1 Method of the Study - This study was used both quantitative, and qualitative data. The goal of using the two methods that "bring together the different capability and non-overlapping weaknesses of quantitative methods with those of qualitative methods" (Creswell and Plano Clark, 2007; Johnson, and Onwuegbuzie, 2004; Kelle, 2006). Using survey research method, both quantitative and qualitative data will be collected from teenagers who are studying in Wajed Memorial Model School, Shahed Hemayet Uddin Secondary Girls High School and Khalilur Rahaman Degree College at Mollahat Upazila in Bagerhat District. Generally, we will utilize the Survey Method as well as prepared Questionnaires.
3.2 Study Area - The study area will include Mollahat Upazila in Bagerhat District.

3.3 Unit of Analysis - The unit of measure is the crucial entity that is being tested in a study. It is the 'what' or who that is being studied. In social science research, typical units of investigation include individual, groups, social organization and social artifacts. Here we will discuss the SNSs and its effect on the interpersonal relationship among teenagers.

3.4 The Population of the Study - Now we are identifying the target population, the group of people that we want to paint a conclusion about once the research study is completed. Identifying the target population needs specifying the properties that estimate which individuals are included, and which individuals are not included.

3.5 Sampling Procedure and Sample Size - Sampling technique was used for choosing a sub-group from the population to join in the study. Probability sampling approach has been utilized to develop a suitable sample size. With a view to choosing a representative a sample, simple random sampling method has been employed. So, the researcher conducted this research, especially purposive sampling.

3.6 Sources of Data - For the research purpose, we will utilize secondary data from the various journal, newspapers, conducted research as well as primary data from direct interview and survey method.

3.7 Study Instrument - Questionnaire was used as the main data collection instrument for this study. For collecting the necessary information, a semi-structured questionnaire with a series of the close-and openended question was used.

3.8 The Technique of Data Collection - The data collection technique for this study was a survey which is the most widely used data-gathering technique in Sociology. It is particularly strong when the answers respondents give to questions measure variables. Instead of a face-to-Face survey, the self-administrated questionnaire was considered more convenient for this study. Questionnaire both structure and semi-structure, open-ended, and close-ended question are used. 
3.9 Techniques of Data Processing - Since the collected data in itself does not contain meaning, the act of data processing and analysis has the objectives of bringing meaning to the data and displays it to the reader. Firstly, the data has been edited and then has been coded and tabulated. At last all data were input into computer through software of Social Research SPSS.

3.10 Analysis and Interpretation of Data - Assess of data is a process of examining, cleansing, transforming, and modeling fact with the major goal of discovering helpful information, suggesting conclusion and supporting resolve making. We used the mixed variety of data analysis. Some statistical techniques and procedure, charts such as pie chart, bar diagram, tables in terms of data analysis has been used.

\section{RESULTS AND DISCUSSION}

\subsection{Socio-economic and Demographic Features of the Respondents.}

Table 1: Age of the Respondents.

\begin{tabular}{|lll|}
\hline Valid & Frequency & Percent \\
\hline 14 years & 3 & 8.6 \\
\hline 15 years & 7 & 20.0 \\
\hline 16 years & 4 & 11.4 \\
\hline 17 years & 5 & 14.3 \\
\hline 18 years & 16 & 45.7 \\
\hline Total & 35 & 100.0 \\
\hline
\end{tabular}

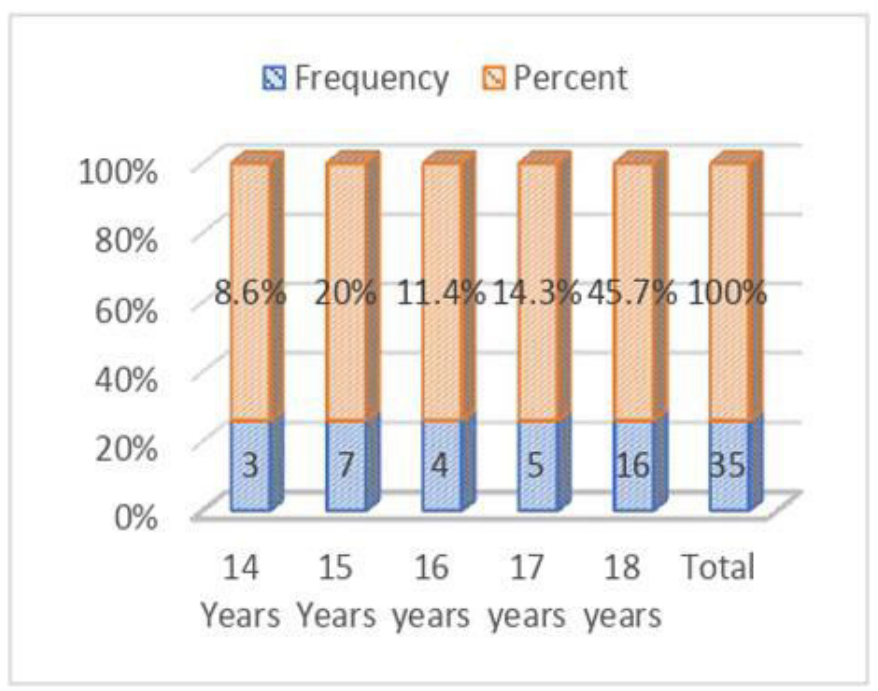

Fig 1: Various age levels of Respondents.
3.11 Data Validation - Data collected in this research through the social survey is compared to the views given by the respondents. Moreover, relevant research findings on the effect of SNSs on the interpersonal relationship among teenager are also examined to find the relevance of the data gathered in the research.

3.12 Ethical Consideration - Ethical issues are very important for doing social research. The researcher has tried her level best to maintain the values, norms, and ethics of the research. In this research work, respondents' rights to privacy and confidentiality have been kept secure. No efforts were made to force respondents to do or tell anything unwilling or to harm them.

This Research shows the age categories of the respondents. An overwhelming majority of $45.7 \%$ was 18 years old while $8.6 \%$ were between 14 years old, $20 \%$ are 15 years, $11.4 \%$ are 16 years, and $14.3 \%$ are 17 years old, this indicates that all of the respondents belonged in the teenage years, with majority falling between mid and late teenager.

Table 2: Gender of the Respondents.

\begin{tabular}{|lll|}
\hline Valid & Frequency & Percent \\
\hline Female & 15 & 42.8 \\
\hline Male & 20 & 57.1 \\
\hline Total & 35 & 100.0 \\
\hline
\end{tabular}

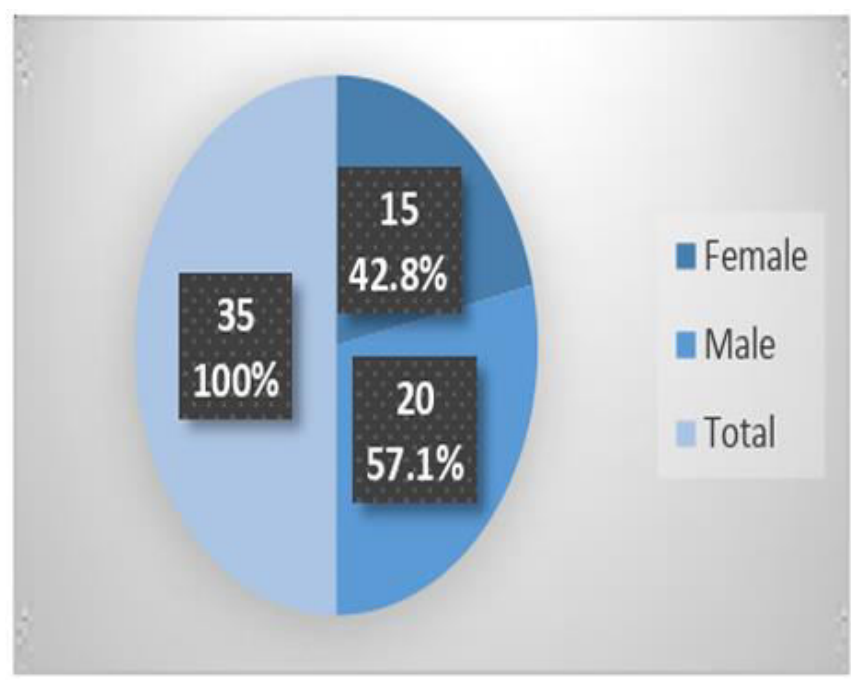

Fig 2: Gender of the Respondents. 


\subsection{Study of the Purpose of Usages SNSs Sites.}

Table 3: Respondents normally have account.

\begin{tabular}{|lll|} 
Valid & Frequency & Percent (\%) \\
\hline Twitter & 2 & 5.8 \\
\hline You tube & 7 & 19.8 \\
\hline Facebook & 23 & 65.7 \\
\hline Whats app & 1 & 2.9 \\
\hline Imo & 2 & 5.8 \\
\hline Total & 35 & 100.0 \\
\hline
\end{tabular}

The respondents were asked the SNSs they had accounts with. Findings show that $65.7 \%$ of the respondents said they had accounts on Facebook. $19.8 \%$ said they had an account in youtube, $5.8 \%$ said they had an account on Twitter, 2.9\% said they had an account Whatsapp, 5.8\% said they had an account on imo. The majority are used Facebook.

Table 4: Respondents favorite levels of SNSs.

\begin{tabular}{|lll|}
\hline Valid & Frequency & Percent \\
\hline Facebook & 23 & 65.7 \\
\hline Facebook and Imo & 2 & 5.8 \\
\hline Facebook and whatsapp & 1 & 2.7 \\
\hline Facebook and You tube & 2 & 5.8 \\
\hline Imo & 2 & 5.7 \\
\hline You tube & 5 & 14.3 \\
\hline Total & 35 & 100.00 \\
\hline
\end{tabular}

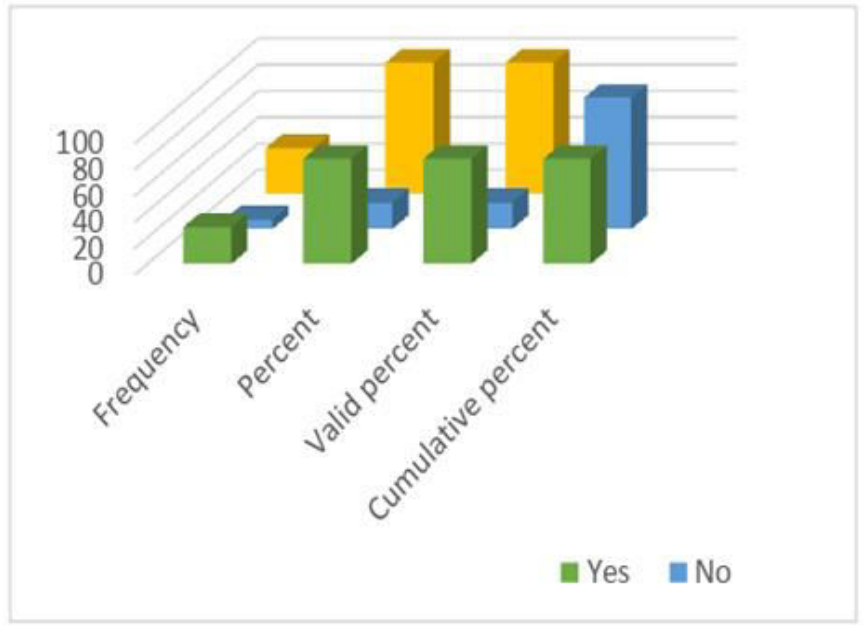

Fig 3: Account on Social Networking Sites (SNSs).

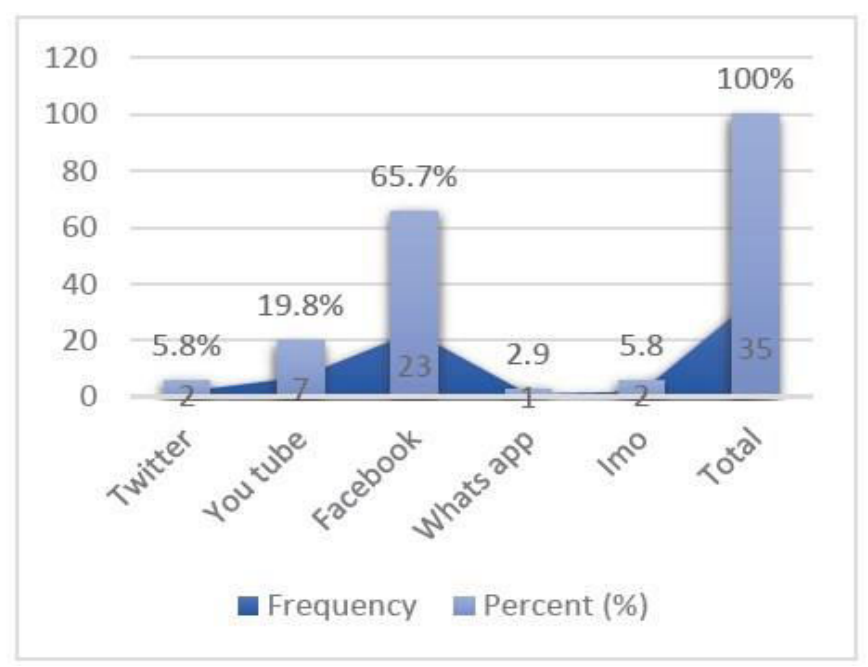

Fig 4: Affect speak and writing style by SNSs.

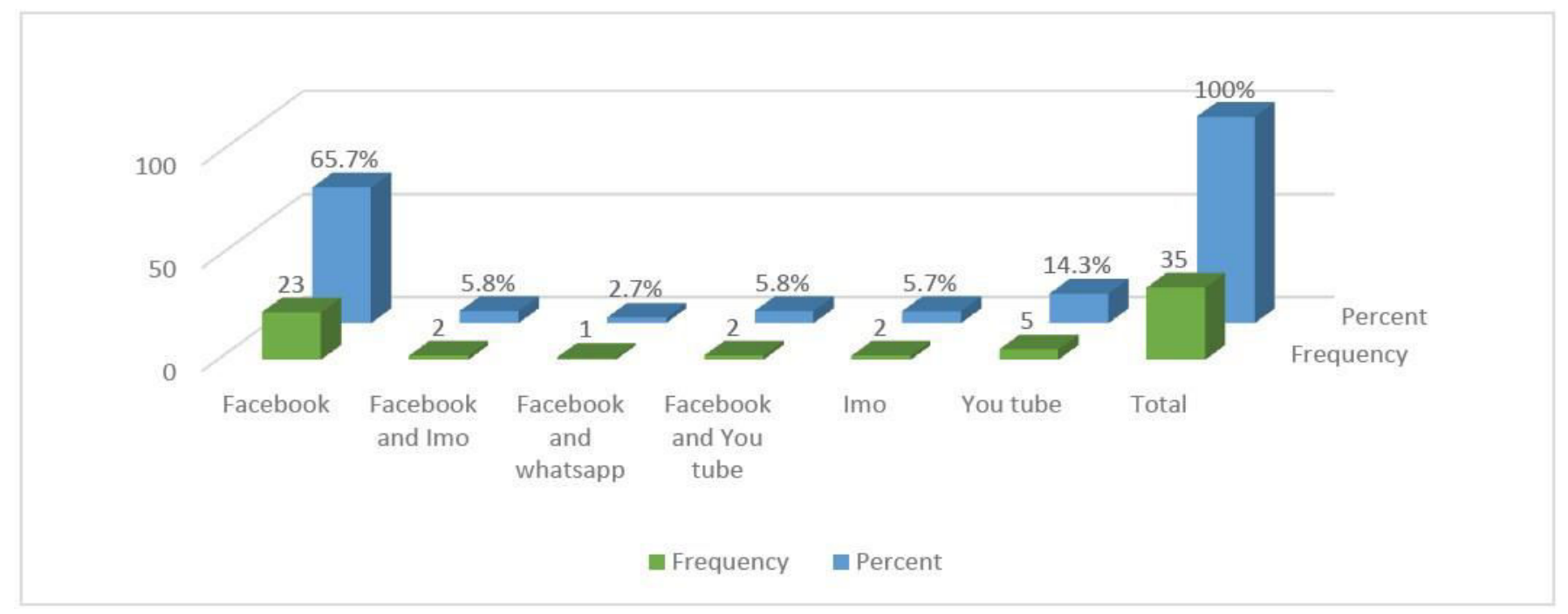

Fig 5: Respondents favorite level of SNSs. 
The respondents were further asked about their favorite social networking site. The study finds out that $65.7 \%$ of the respondents cited Face book as their favorite social networking site, 5.8\% Cited Facebook and Imo, 2.7\% mentioned Facebook and Whatsapp, 5.8\% mentioned Facebook and Youtube, and 5.7\% mentioned only YouTube and $14.3 \%$ of the respondents cited $14.3 \%$. This shows that Face book is the most popular among teenagers among the listed SNSs.

Table 5: Respondents gets access to their favorite SNSs.

\begin{tabular}{|lll|} 
Valid & Frequency & Percent $(\boldsymbol{\%})$ \\
\hline Laptop & 4 & 11.4 \\
\hline Android Mobile & 31 & 88.6 \\
\hline Total & 35 & 100.0 \\
\hline
\end{tabular}

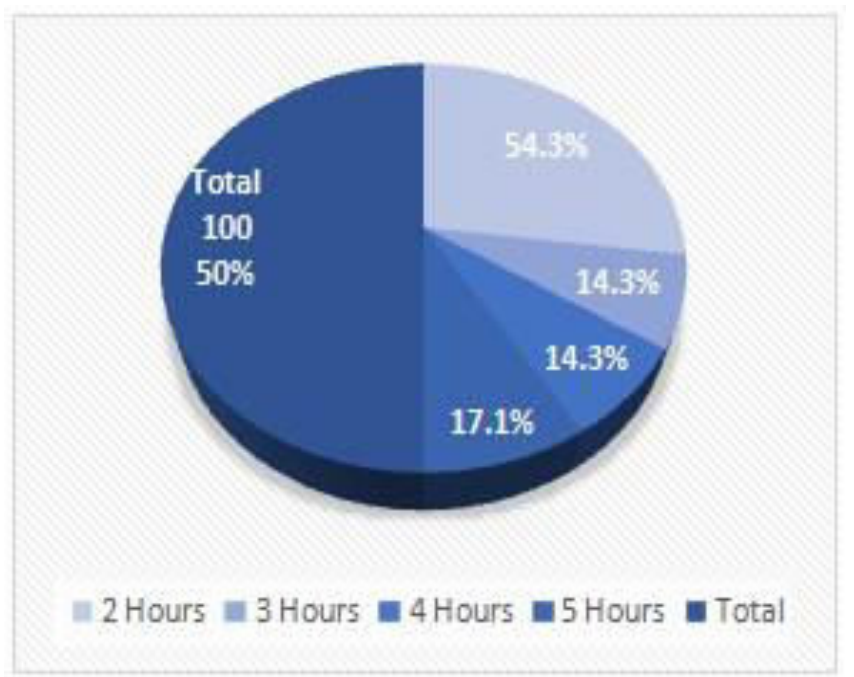

Fig 6: Average time spend in online every day.

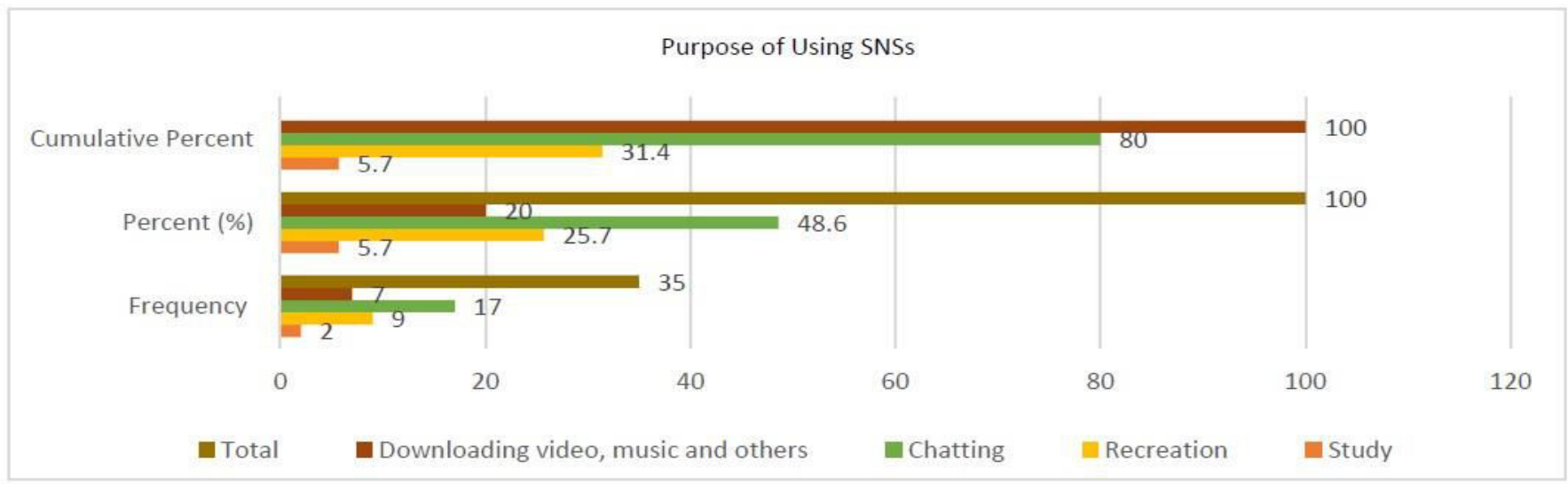

Fig 7: Different purposes of using SNSs sites by Respondents.

The study finds out how the respondents got access to their favorite social networking site. Most of the respondents $88.6 \%$ utilize Android mobile phones rather than they utilize Laptop.

Table 6: Purpose of Using SNSs.

\begin{tabular}{|llll|} 
Valid & Frequency & $\begin{array}{l}\text { Percent } \\
(\%)\end{array}$ & $\begin{array}{l}\text { Cumulative } \\
\text { Percent }\end{array}$ \\
\hline Study & 2 & 5.7 & 5.7 \\
\hline Recreation & 9 & 25.7 & 31.4 \\
\hline Chatting & 17 & 48.6 & 80.0 \\
\hline $\begin{array}{l}\text { Downloading } \\
\text { video, music } \\
\text { and others }\end{array}$ & 7 & 20.0 & 100.0 \\
\hline Total & 35 & 100.0 & \\
\hline
\end{tabular}

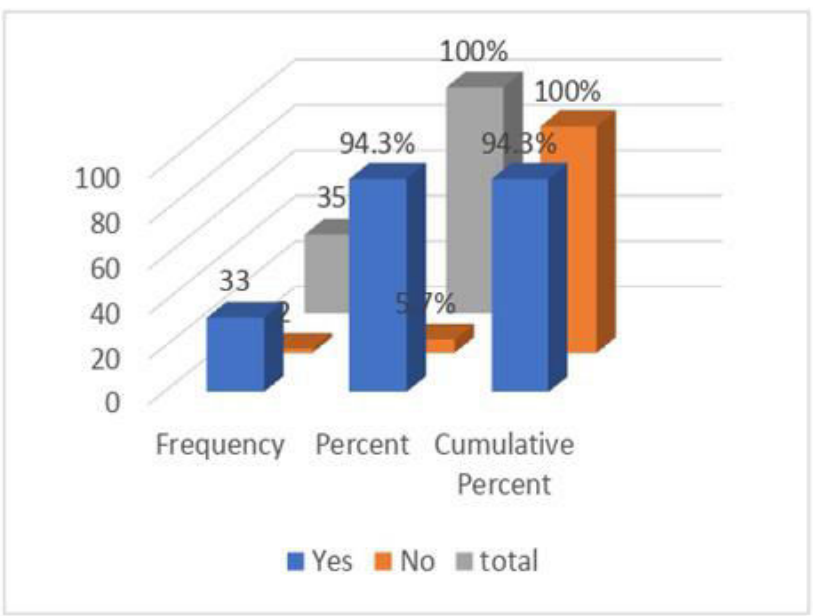

Fig 8: Respondents view about the importance of SNSs. 
Researchers have found that teenagers find imagine ways to gain access to newer technologies, participate in various online Medias that help them in many ways. Only $5.7 \%$ respondents said that they utilize SNSs for study, $25.5 \%$ are used for recreation, most of them utilize for chatting with friends cited 48.6\%, $(20.0 \%)$ are used for downloading video, music and other purpose.

\subsection{SNSs and Interpersonal Relationship.}

Table 8: Respondents like most doing in online.

\begin{tabular}{|llll|}
\hline Valid & Frequency & Percent & Cumulative Percent \\
\hline Chatting & 16 & 45.7 & 45.7 \\
\hline Chatting and downloading & 1 & 2.9 & 48.6 \\
\hline Chatting and watching Video & 1 & 2.9 & 51.4 \\
\hline Chatting, Watching video & 1 & 2.9 & 54.3 \\
\hline Gaming and chatting & 1 & 2.9 & 57.1 \\
\hline News and chatting & 1 & 2.9 & 60.0 \\
\hline News and class lecture download & 1 & 2.9 & 62.9 \\
\hline Reading News & 3 & 8.6 & 71.4 \\
\hline Try to get Educational Information & 1 & 2.9 & 74.3 \\
\hline Video chat & 1 & 2.9 & 77.1 \\
\hline Video Download & 1 & 2.9 & 80.0 \\
\hline Watching body building motivational video & 1 & 2.9 & 82.9 \\
\hline Watching movie & 1 & 2.9 & 85.7 \\
\hline Watching news and video & 1 & 2.9 & 88.6 \\
\hline Watching video & 3 & 8.6 & 97.1 \\
\hline Watching video and drama & 1 & 2.9 & 100.0 \\
\hline Total & $\mathbf{3 5}$ & $\mathbf{1 0 0 . 0}$ & \\
\hline
\end{tabular}

The Research illustrates that the majority of teenagers $(45.7 \%)$ are like chatting online. Respondents also like downloading video, watching movie and drama, reading News and many other activities through SNSs sites.

Table 9: Average time spends in online every day.

\begin{tabular}{|lll|}
\hline Valid & Frequency & Percent $(\%)$ \\
\hline 2 Hours & 19 & 54.3 \\
\hline 3 Hours & 5 & 14.3 \\
\hline 4 Hours & 5 & 14.3 \\
\hline 5 Hours & 6 & 17.1 \\
\hline Total & 35 & 100.0 \\
\hline
\end{tabular}

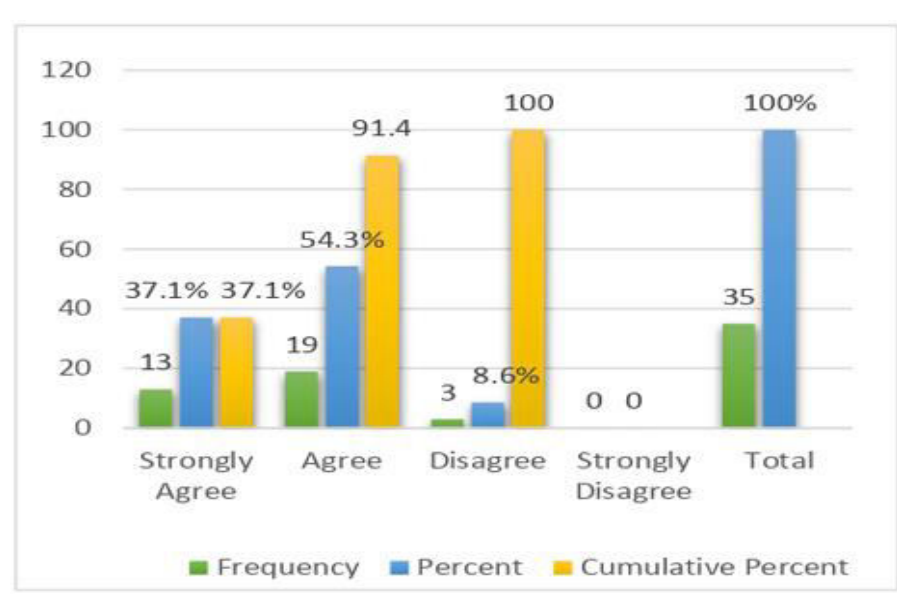

Fig 9: Respondents average keeps in touch with friends online than offline.
Table 7: SNSs affect speak or writing of the Respondents:

\begin{tabular}{|lllll|}
\hline Valid & Frequency & Percent & $\begin{array}{l}\text { Valid } \\
\text { percent }\end{array}$ & $\begin{array}{l}\text { Cumulative } \\
\text { percent }\end{array}$ \\
\hline Yes & 28 & 80.0 & 80.0 & 80.0 \\
\hline No & 7 & 20.0 & 20.0 & 100.0 \\
\hline Total & 35 & 100.0 & 100.0 & \\
\hline
\end{tabular}

The study went to find out those SNSs affect speak and writing the style of the respondents. Here $80 \%$ of respondents said that SNSs affect or change their writing and speaking style on the other hand $20 \%$ said that SNSs don't affect them. 
The respondent was asked how much time they spend on SNSs. The study shows that (54.3\%) are spending

Table 10: SNSs are important, respondent view.

\begin{tabular}{|llll|}
\hline Valid & Frequency & $\begin{array}{l}\text { Percent } \\
(\%)\end{array}$ & $\begin{array}{l}\text { Cumulative } \\
\text { Percent }\end{array}$ \\
\hline Yes & 33 & 94.3 & 94.3 \\
\hline No & 2 & 5.7 & 100.0 \\
\hline total & 35 & 100.0 & \\
\hline
\end{tabular}

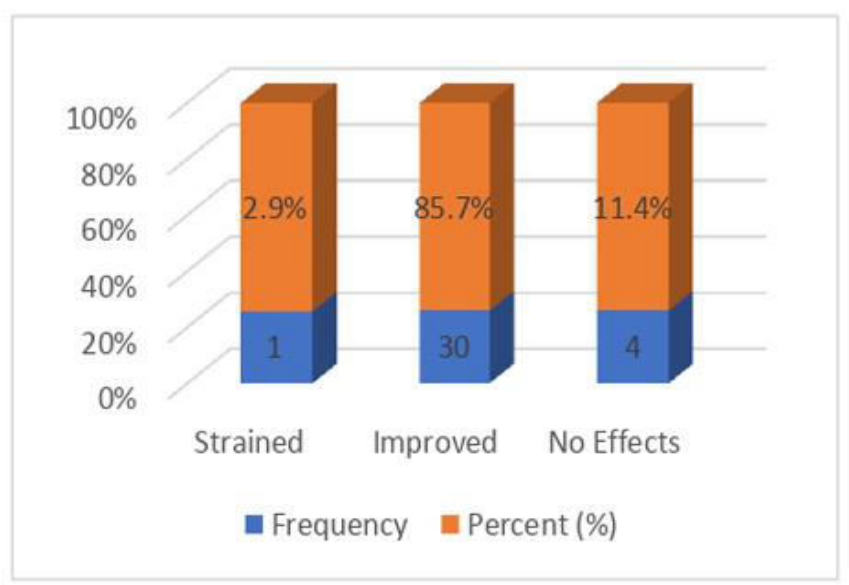

Fig 10: Affect relationship with friends.

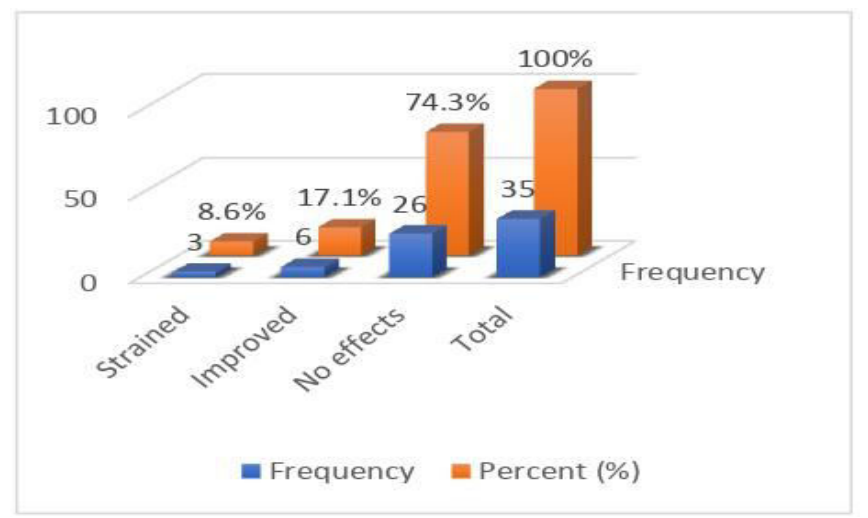

Fig 11: Relationship status with the parents. time in online 2 hours, (14.3\%) 3 and 4 hours, (17.1\%) 5 hours.

Majority of the Respondents viewed that SNSs are important for many purposes.

Table 11: SNSs affect face to face relationship.

\begin{tabular}{|llll|}
\hline Valid & Frequency & $\begin{array}{l}\text { Percent } \\
(\%)\end{array}$ & $\begin{array}{l}\text { Cumulative } \\
\text { Percent }\end{array}$ \\
\hline Yes & 17 & 48.6 & 48.6 \\
\hline No & 18 & 51.4 & 100.0 \\
\hline Total & 35 & 100.0 & \\
\hline
\end{tabular}

Majority of the respondents $(51.4 \%)$ said that SNSs does not affect Face to Face relationship and $48.6 \%$ respondents said SNSs affect their relationship and most of them are given the positive answer that SNSs are helping to communicate with acquaintances member more than before. It also helps to strengthen relation with acquaintances member.

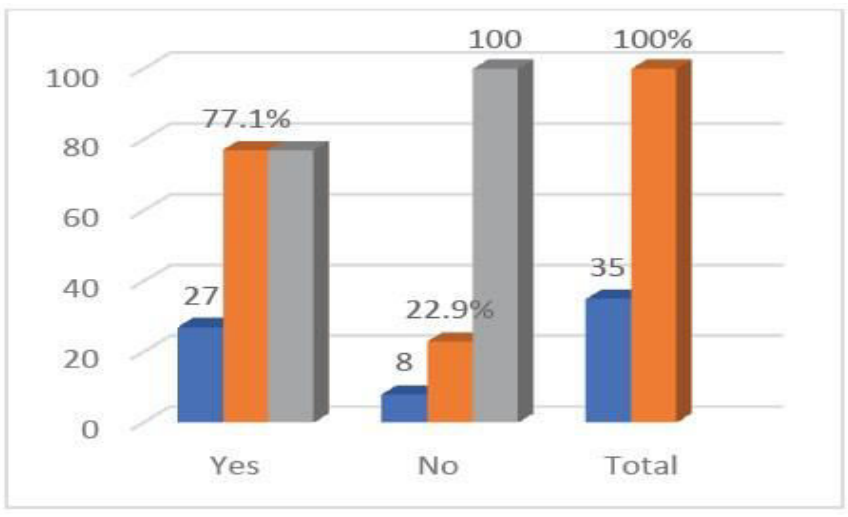

Fig 12: Changes of the relationship with friends.

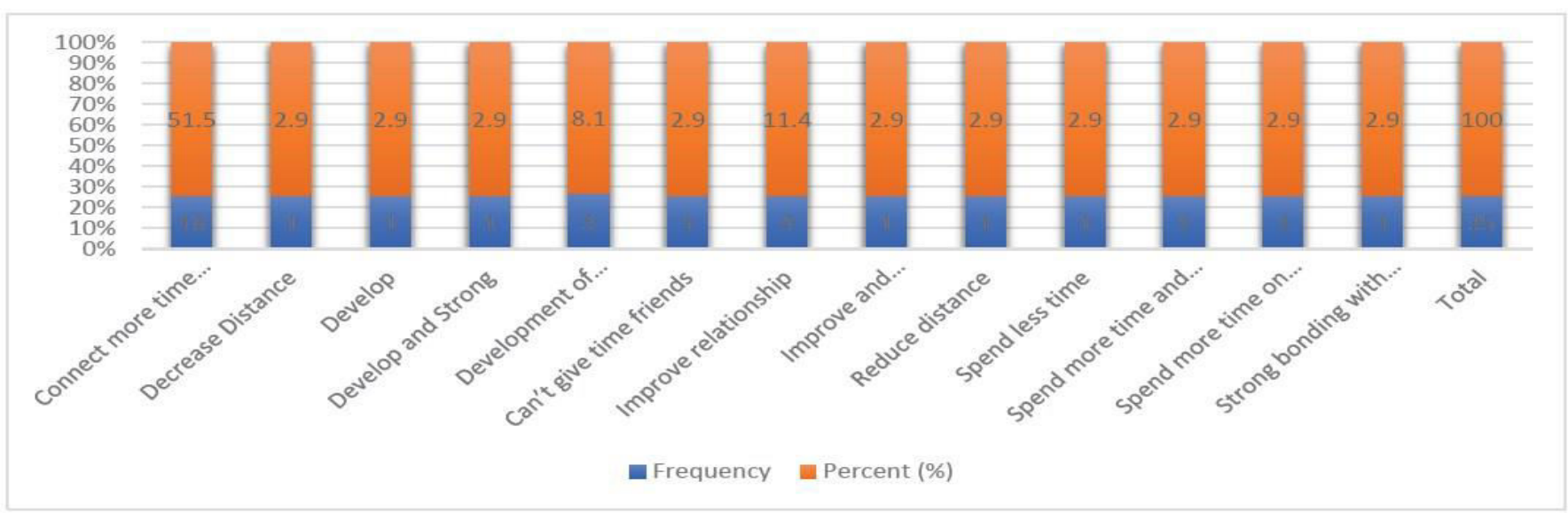

Fig 13: Changing categories of close relationship. 
Table 12: Various kind of changes in close relationship by using SNSs.

\begin{tabular}{|lll|}
\hline Valid & Frequency & Percent (\%) \\
\hline Connect more time family and friend & 18 & 51.5 \\
\hline Decrease Distance & 1 & 2.9 \\
\hline Develop & 1 & 2.9 \\
\hline Develop and Strong & 1 & 2.9 \\
\hline Development of friendship & 3 & 8.1 \\
\hline Can't give time friends & 1 & 2.9 \\
\hline Improve relationship & 4 & 11.4 \\
\hline Improve and strengthen relation & 1 & 2.9 \\
\hline Reduce distance & 1 & 2.9 \\
\hline Spend less time & 1 & 2.9 \\
\hline Spend more time and strong bonding & 1 & 2.9 \\
\hline Spend more time on SNSs so decrease relation with nearer & 1 & 2.9 \\
\hline Strong bonding with Friends & 1 & 2.9 \\
\hline Total & 35 & 100.0 \\
\hline
\end{tabular}

Table 13: SNSs are easier to keep touch with friends online than offline.

\begin{tabular}{|llll|} 
Valid & Frequency & $\begin{array}{l}\text { Percent } \\
(\%)\end{array}$ & $\begin{array}{l}\text { Cumulative } \\
\text { Percent }\end{array}$ \\
\hline $\begin{array}{l}\text { Strongly } \\
\text { Agree }\end{array}$ & 13 & 37.1 & 37.1 \\
\hline Agree & 19 & 54.3 & 91.4 \\
\hline Disagree & 3 & 8.6 & 100.0 \\
\hline $\begin{array}{l}\text { Strongly } \\
\text { Disagree }\end{array}$ & 0 & 0 & \\
\hline Total & 35 & 100.0 & \\
\hline
\end{tabular}

The study digs out that $37.1 \%$ strongly agreed and $54.3 \%$ agreed they found it easier to connect with friends online than offline. Only $8.6 \%$ is said that it is not easy to link with friends online.

Table 14: SNSs affect the relationship with friends.

\begin{tabular}{|llll|} 
Valid & Frequency & $\begin{array}{l}\text { Percent } \\
(\%)\end{array}$ & $\begin{array}{l}\text { Cumulative } \\
\text { Percent }\end{array}$ \\
\hline Yes & 27 & 77.1 & 77.1 \\
\hline No & 8 & 22.9 & 100.0 \\
\hline Total & 35 & 100.0 & \\
\hline
\end{tabular}

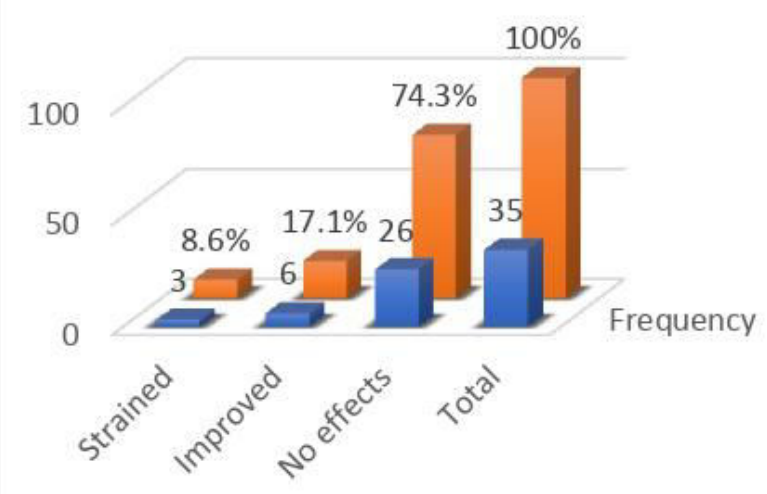

Frequency $=$ Percent (\%)

Fig 14: Easier to express an opinion through SNSs.
Majority of the respondents (77.1\%) said that SNSs affect their relationship with friends and $22.9 \%$ said that SNSs don't affect their relationship.

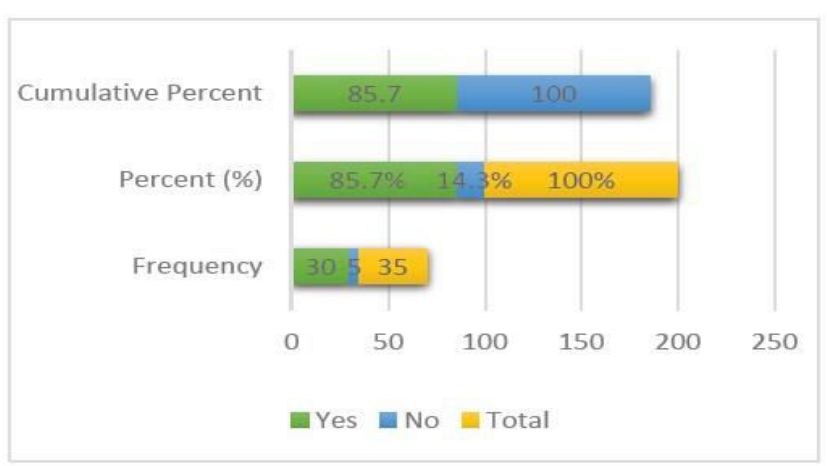

Fig 15: Average decrease the distance by using SNSs. 
Table 15: Change the relationship with friends.

\begin{tabular}{|lll|} 
Valid & Frequency & Percent $(\%)$ \\
\hline Strained & 1 & 2.9 \\
\hline Improved & 30 & 85.7 \\
\hline No Effects & 4 & 11.4 \\
\hline
\end{tabular}

The research shows that SNSs improved the relationship with friends and $85.7 \%$ agree with the statement only $2.9 \%$ are stand opposite it.

Table 16: Change the Relationship with parents.

\begin{tabular}{|lll|} 
Valid & Frequency & Percent $(\%)$ \\
\hline Strained & 3 & 8.6 \\
\hline Improved & 6 & 17.1 \\
\hline No effects & 26 & 74.3 \\
\hline Total & 35 & 100.0 \\
\hline
\end{tabular}

Majority of the respondents $(74.3 \%)$ said that relationships with parents are the same as before when they don't utilize SNSs and $17.1 \%$ said their relation is improved and $8.6 \%$ mentioned that their relationship with parents is strained day by day.

\subsection{The Benefit of using SNSs.}

Table 17: Easier to express an opinion through SNSs.

\begin{tabular}{|llll|} 
Valid & Frequency & $\begin{array}{l}\text { Percent } \\
(\%)\end{array}$ & $\begin{array}{l}\text { Cumulative } \\
\text { Percent }\end{array}$ \\
\hline Yes & 35 & 100.0 & 100.0 \\
\hline No & 0 & 0 & \\
\hline Total & 35 & 100.0 & \\
\hline
\end{tabular}

All the respondents said that SNSs are an easy way to express the opinion of any comments.

Table 18: SNSs decreased the distance.

\begin{tabular}{|llll|}
\hline Valid & Frequency & $\begin{array}{l}\text { Percent } \\
(\%)\end{array}$ & $\begin{array}{l}\text { Cumulative } \\
\text { Percent }\end{array}$ \\
\hline Yes & 30 & 85.7 & 85.7 \\
\hline No & 5 & 14.3 & 100.0 \\
\hline Total & 35 & 100.0 & \\
\hline
\end{tabular}

Table 19: SNSs Strengthen interpersonal Relationship.

\begin{tabular}{|lll|}
\hline Valid & Frequency & Percent $(\%)$ \\
\hline Yes & 30 & 85.7 \\
\hline No & 5 & 14.3 \\
\hline Total & 35 & 100.0 \\
\hline
\end{tabular}

SNSs are an easy way to decrease distance and $85.7 \%$ respondents agree with this, $14.3 \%$ are said SNSs are not decrease distance it increases distance.

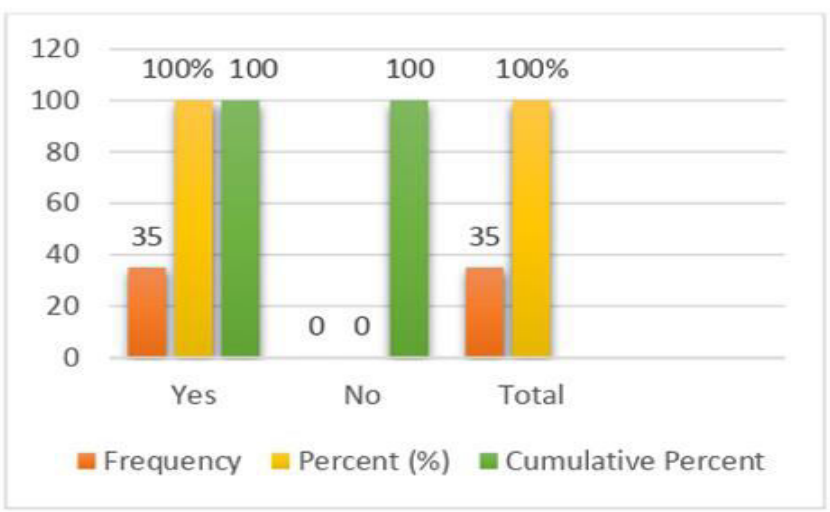

Fig 16: SNSs strengthening of interpersonal relationship.

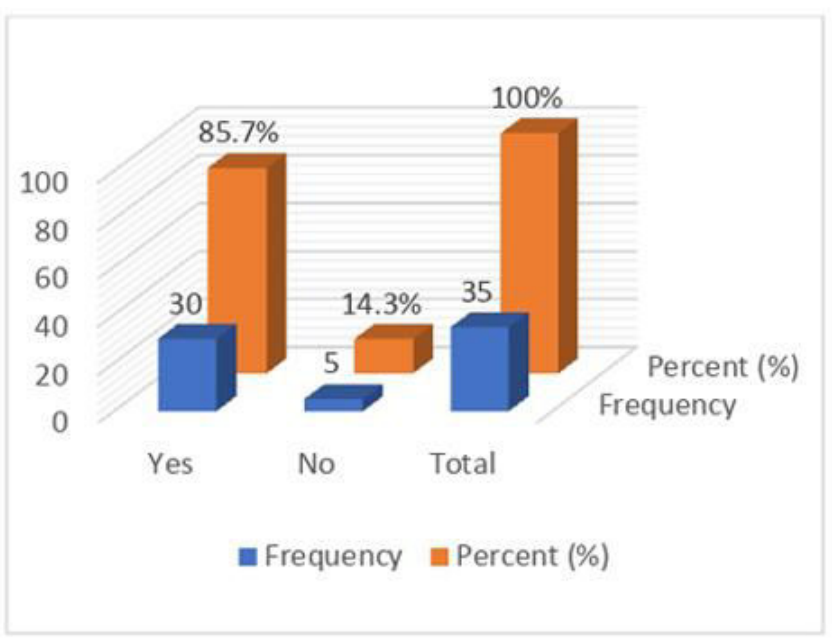

Fig 17: SNSs influences cognitive development.

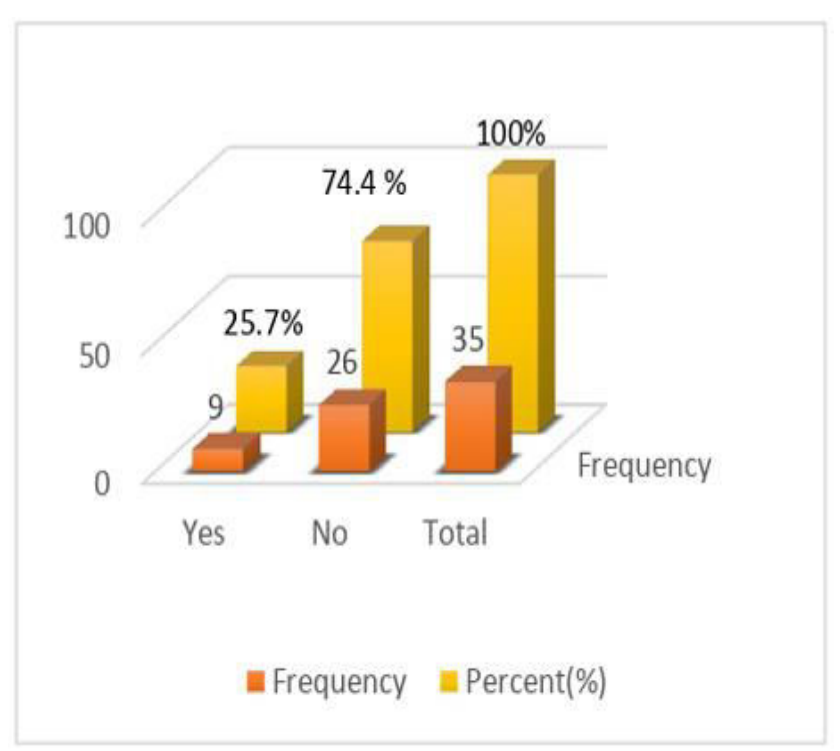

Fig 18: Respondents addicted with the SNSs. 
SNSs are a benefit because it also helps to strengthen interpersonal relationship and $85.5 \%$ mention it and $14.3 \%$ disagree with it.

Table 20: Status of the cognitive development.

\begin{tabular}{|lll|} 
Valid & Frequency & Percent (\%) \\
\hline Yes & 9 & 25.7 \\
\hline No & 26 & 74.3 \\
\hline Total & 35 & 100 \\
\hline
\end{tabular}

Most of the respondents (74.3\%) mentioned that they normally utilize SNSs and (25.7\%) are addicted to it. SNSs help to the respondents to influence their cognitive development it includes new thinking and all the respondents mentioned it.

\subsection{The Danger associated with SNSs.}

Table 21: Addicted with the utilize of SNSs.

\begin{tabular}{|llll|} 
Valid & Frequency & $\begin{array}{l}\text { Percent } \\
(\%)\end{array}$ & $\begin{array}{l}\text { Cumulative } \\
\text { Frequency }\end{array}$ \\
\hline Yes & 28 & 80.0 & 80.0 \\
\hline No & 7 & 20.0 & 100.0 \\
\hline Total & 35 & 100.0 & \\
\hline
\end{tabular}

Table 22: Status of the crime and immoral activities.

\begin{tabular}{|lll|}
\hline Valid & Frequency & Percent (\%) \\
\hline Highly Secured & 12 & 34.3 \\
\hline Lack of Privacy & 23 & 65.7 \\
\hline Total & 35 & 100.0 \\
\hline
\end{tabular}

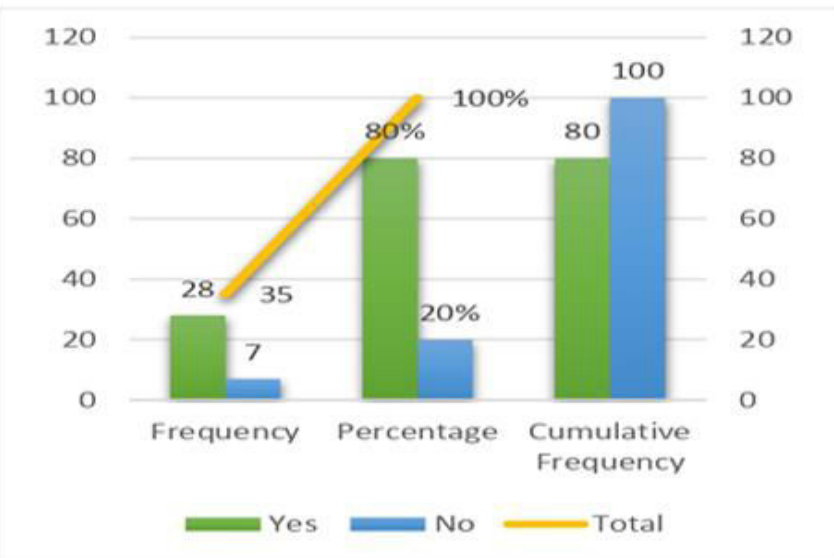

Fig 19: Increase the crime and immoral activities.

Above $80.0 \%$ respondents said SNS increase crime and immoral act and $20.0 \%$ don't mention it.

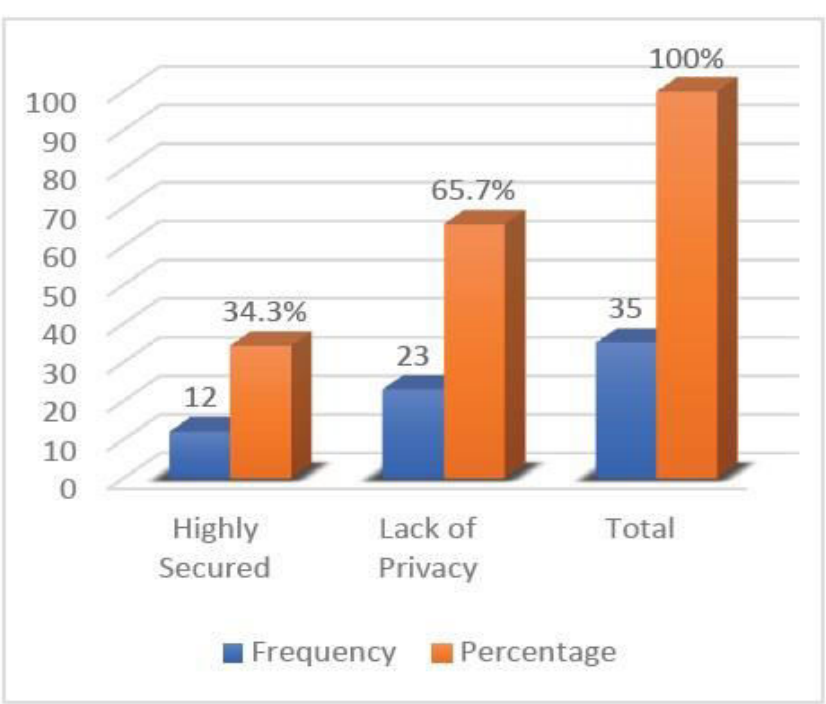

Fig 20: Nature of using of SNSs.

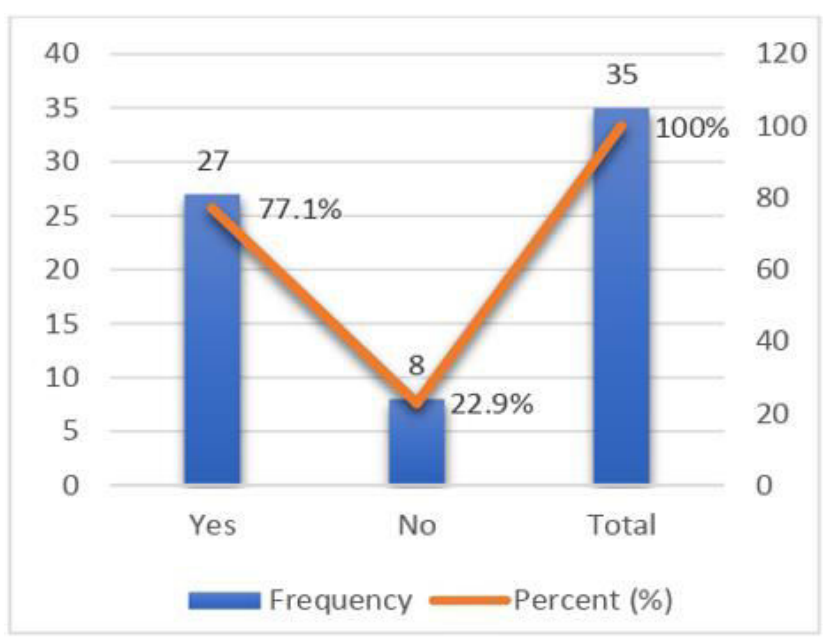

Fig 21: SNSs waste the valuable time.

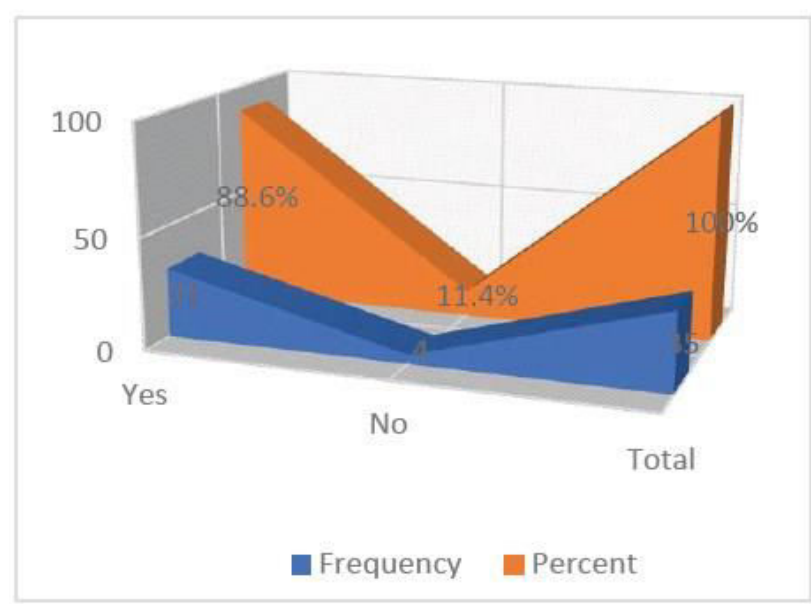

Fig 22: Increase of the monthly expenditure by SNSs. 
Table 23: Nature of the using the SNSs.

\begin{tabular}{|llll|} 
Valid & Frequency & $\begin{array}{l}\text { Percent } \\
(\%)\end{array}$ & $\begin{array}{l}\text { Cumulative } \\
\text { Percent }\end{array}$ \\
\hline Yes & 35 & 100.0 & 100.0 \\
\hline No & 0 & 0 & 100.0 \\
\hline Total & 35 & 100.0 & \\
\hline
\end{tabular}

SNSs are highly secured $65.7 \%$ said that and $34.3 \%$ said SNSs has lack of privacy.

Table 24: SNSs waste valuable time from life.

\begin{tabular}{|lll|}
\hline Valid & Frequency & Percent $(\%)$ \\
\hline Yes & 27 & 77.1 \\
\hline No & 8 & 22.9 \\
\hline Total & 35 & 100.0 \\
\hline
\end{tabular}

\section{CONCLUSION:}

The study set to examine that SNSs have created a phenomenon over the past decade. Facebook and Youtube have emerged as the most in favor websites and have continued to cultivate in popularity. These websites build new ways of communication and set a new way of relationships with friends and family and also influence an individual's self-concept. SNSs also offer new and innovative ideas to meet with other individuals in a quick response. Computer based communication provides individuals with easy and faster ways of communication. In addition, individuals are using different social media websites at enlarge rates, and visiting them quite frequently. This study makes a pivotal contribution to understanding college and school student's utilize of SNSs and its impact on communication and their interpersonal relationships. SNSs had various impacts on the interpersonal relationships of the teenagers both online and offline. For instance, some of them would rather chat with an online friend than stage a face to face talk, this is because face to face may inhibit the teenagers from expressing themselves openly especially to members of the incompatible sex. The study also concludes that, although the SNSs have aided improve relationships among close teenagers as friends. The research showed that teenagers have become addicted to SNSs. The usage of SNS brought lots of changes in interpersonal relationships between these students and members of the family and it also helped students to have more
SNSs waste time of the respondent and $77.1 \%$ are mentioned it and $22.9 \%$ are standing opposite the statement.

Table 25: Increase the monthly expenditure.

\begin{tabular}{|cll|}
\hline Valid & Frequency & Percent \\
\hline Yes & 31 & 88.6 \\
\hline No & 4 & 11.4 \\
\hline Total & 35 & 100.0 \\
\hline
\end{tabular}

Most of the respondents utilize SNSs through buy internet package that increases their expenditure, $88.6 \%$ are mentioned it and $11.4 \%$ their expenditure is not changed.

communication with their family members. To build and maintain a relationship, it is a process of communicating and the level of revelation of personal thoughts and feelings. Bad communication is one of the major factors that harm interpersonal relationships.

\section{ACKNOWLEDGEMENT:}

This research was supported with proper guidance in the Dept. of Sociology, Bangabandhu Sheikh Mujibur Rahman Science, and Technology University, Gopalganj, Bangladesh. Heartiest thanks to the coauthors for helping us to conduct the successful research work.

\section{CONFLICTS OF INTEREST:}

The authors declared no prospective conflicts of the interest with respect to the research.

\section{REFERENCES:}

1. Al-Otaibi J. (2008). The impact of Facebook on Saudi university students (Unpublished master's thesis). Faculty of Arts, King Saud University, Riyadh, Saudi Arabia.

2. Berlinger M. R. (2000). Internet and alienation. The New York Times.

https://www.nytimes.com/2000/02/23/opinion/1internet-and-alienation-946346.html

3. Bicen Huseyin and Cavus Nadire (2010). "The Most Used Social Network Sites by Students" Procedia Social, and Behavioral Sciences, 2, 5864-5869. 
4. Boyd D. \& Ellison N. (2008). Social network sites: Definition, history, and scholarship. J. of Computer-Mediated Communi., 13, 210-230. https://doi.org/10.1111/j.1083-6101.2007.00393

5. Creswell W. John, Plano Clark, and Vicki L. (2007). Designing, and conducting mixed approaches research. Thousand Oaks, CA: Sage publication.

6. Ellison N. B., Steinfield C., \& Lampe C. (2007). The benefits of Facebook "friends:" Social capital and college students' utilize of online social network sites. J. of ComputerMediated Communication, 12(4), article 1. https://doi.org/10.1111/j.1083-6101.2007.00367.x

7. Folorunso Olusegun (2010). "Diffusion of Innovation in SNS among University Students". International J. of Computer Science and Security, 4(3), 361-372.

8. Geetanjali Naidu \& Sunil Agrawal (2013). A Study on the effect of Social Media in Buying Behavior of Customer with Specific Reference to Raipur, J. of Harmonized Research in App. Sci., 1(3), 98-101.

http://citeseerx.ist.psu.edu/viewdoc/download?d oi=10.1.1.403.5769\&rep=rep1\&type $=$ pdf

9. Ito M., Baumer Bittanti S. (2009). Hanging out, messing around, and seeking out: Child living, and learning with newer media. Cambridge, MA: MIT Press

10. Johnson, Onwuegbuzie and Fox T. MacArthur (2009). Foundation Series on Modern Media, and Learning. Cambridge, MA: MIT Press.

11. Kraut R., Kiesler S. (2002). Internet paradox revisited. J. of Social Issues, 58(1), 49-74. https://www.dhi.ac.uk/san/waysofbeing/data/co mmunication-zangana-kraut-2002.pdf

12. Ledbetter (2011). Attitudes toward online social link, and self-disclosure as predictors of Facebook communication, and relational closeness. Research, 38(1), 27-53.
13. McCarthy A. (2009). Social penetration theory, social networking, and Facebook.

14. Mecheel V. (2010). Facebook and the invasion of technological communities. NY: New York.

15. Nasrin Akter (2012). 'Social Networking and the Youth', Master's thesis, Department of Sociology, University of Dhaka, Bangladesh.

16. Shahjahan Chisty and Kutub Uddin Chisty (2014). "World Academy of Science, Engineering and Technology". International J. of Social, Behavioral, Educational, Economic, Business, and Industrial Engi., 8(6), 11-22. https://publications.waset.org/9998891/pdf

17. Shim Young S. (2007). The impact of the Internet on teenagers' face-to-face communication. Global Media J., 6(10), e2237.

18. Thawhidul Kabir (2008). 'Exploitation of SNSs and Its impact on students Academic Results' BUBT, Bangladesh.

19. Thorstein Veblen (2010). Mom just Facebooked me and dad knows how to text. The Elon J. of Undergraduate Research in communications, 1, 5-16.

20. Tiffany (2009). College students' social networking experiences on Facebook, J. of Applied Developm. Psychology, 30, 227-238. https://doi.org/10.1016/j.appdev.2008.12.010

21. Vitak (2008). "Facebook Friends: How Online identities Impact Offline Relations".

22. WaratKaruchit (2013). Media affects theories. Communication Theories and Innovation Communication. Bangkok: National Institute of Development Administration.

23. Won, Kim, and Sang-WonLee. (2009). "On Social Websites". Information Systems. World Academy of Sci., Eng. and Technol.

24. Xiang Z. \& Gretzel U. (2010). Role of Social Media in Online Travel Information Search, Tourism Management, 31(2), 179-188.

25. Zeng B. (2013). Social Media in Tourism, J. of Tourism and Hospitality, 2, 1-2, https://doi.org/10.4172/2167-0269.1000e1

Citation: Parvez MS, Rahaman MA, Fatema K, and Mondal DR. (2019). Impact of social networking sites on the interpersonal relationship among teenager: a sociological analysis in the district of Bagerhat. Br. J. Arts Humanit., 1(5), 14-27. https://doi.org/10.34104/bjah.019.14027 @ 